\title{
The ecology-driven service (r)evolution: The product longevity approach and its consequences for production and corporate management
}

\author{
H. Hübner, Univ.-Prof. Dipl.-Ing. Dr. habil. \\ Head of Department "Management Science - Technology \\ Impact \& Innovation Research (TWI)", University of Kassel \\ Nora-Platiel-Str. 4, D-34109 Kassel, Germany \\ Tel. +49-561-804-3055, Fax +49-561-804-3186 \\ e-mail: huebner@wirtschaft.uni-kassel.de
}

\begin{abstract}
Development, production, distribution, and relatively short-term use of always new products increasingly hits against ecological limits of availability of natural resources and absorbing capacity of ecosystems for emissions and waste. Therefore, re-orientation of economic activities and a change in the direction and goal of innovations is required. Application of the Product Longevity Approach provides for a stepwise "dematerialization" of economy. To ensure customer benefit, the company has to offer product-related services as a new kind of business which, in addition to maintenance and repair, will provide for technical updating and upgrading. Prerequisites and consequences of this change are dealt with; finally, its practicability is demonstrated by reference to examples.
\end{abstract}

\section{Keywords}

Ecological quality, resource efficiency, product-related service, dematerialization, "lean" product

\section{PREFACE}

The paper describes some results of ongoing research focused on the question in which way individual companies and, consequently, economy as a whole can meet ecological requirements to such extent as to ensure the survival of mankind 
along with adequate quality of life in a really long-term perspective. To reach this overall societal goal, the application of "end-of-the-pipe technologies" like cleaning technology for water, air, soil, etc. - and recycling technology for "old" products $^{1}$, is not sufficient: All these processes again require natural resources and may cause harmful emissions in turn.

The further structure of the paper follows the main questions of interest for experts and decision-makers dealing with issues of the necessary re-orientation of economy.

\section{WHAT: THE PRODUCT LONGEVITY APPROACH (LA)}

The ecological quality of a product may be described as a result of determining its partial qualities related to all stages of a holistic product life cycle model (Hübner \& Simon-Hübner, 1991).

The utilization period of a product is one dimension which influences directly the ecological quality for the utilization phase. As physical goods and their components are representing material and energy necessary for the several production processes and transportation, a longer utilization period generally means higher ecological quality by increasing resource efficiency. The energy embodied in the product and components respectively cannot be recovered for new use, and recycling processes will require additional energy.

As the amount of production-related waste - depending on individual branches of industry - may be several times as much as the mass of the product ${ }^{2}$, the utilization period indirectly influences the ecological quality for the stage of production by avoiding accumulation of production-related waste. As, by reducing new production, the consumption of further new resources will also be reduced, application of the LA implies a comprehensive improvement of ecological quality in the sense of dematerialization.

Duration of product use may be defined as the period of time between first commissioning and final decommissioning of a product.

A distinction may be made between economic and technical duration of product use: The technical duration of use refers to non-repairable goods with constant efficiency (e.g. light bulb, electronic components) over a certain period. For repairable products with decreasing efficiency and operability, we may refer to the economic duration of use, identifying the period during which the consumer maintains the good in operable condition, as the best alternative for reaching an intended goal. Due to this, economic weighing-up between the alternatives repairing and replacing is possible.

\footnotetext{
${ }^{1}$ In Germany, 600,000 tons of clothing (Keller, M., 1994, p. 72) and 900,000 tons of electrical appliances and electronic equipment (ZVEI, 1994, p. 19) have to be disposed of annually.

2 For example, the production-related waste for personal computers is 20 times the weight of a PC, namely $320 \mathrm{kgs}$, including $20 \mathrm{kgs}$ of dangerous "special waste" (cp. Grote, 1994, p. 93).
} 
Decreasing operability of products results from deterioration by wear, aging, corrosion, rupture etc. which, however, affects only specific components (e.g. socalled "wearing parts"). As full operability can be re-gained by measures of maintenance practically as often as wanted for repairable products, only the economic duration of product use is applicable.

Application of the LA is based on some "axioms":

(1) Allowance for reasonable further technological development must be possible on demand of consumers (technological updating and upgrading).

(2) There is no reduced benefit for the customer using long-lived products; the "surplus" is an active contribution towards relief of the ecosphere, to be communicated by the company.

(3) As the price of new long-lived products ${ }^{3}$ may be higher as against shortlived "throw-away" products, different financing and using concepts (such as leasing) may be developed to relieve the customer.

(4) The consequences for the company will not affect the overall goal, namely to ensure its long-range existence.

2 WHY: ECOLOGICAL - I.E. LONG-RANGE ECONOMICAL - CONSTRAINTS AND THE LIMITS OF "TURBO"-INNOVATION

Damage and partly irreversible destruction of the ecosphere with all of its complex ecosystems has become one of the main problems of mankind. ${ }^{4}$ Change of climate, dying forests, extinction of plant and animal species, menace to health, also of humans, worries about the future and aggressiveness of youths ${ }^{5}$, may be mentioned as main effects.

An ecosystem is "the functional unit formed by organisms and environment interlinked by a multitude of mutual relations. The ecosystem has a certain regulating force, by failure of which the system will be destroyed" (Bund für Umwelt- und Naturschutz, 1988, p. 248).

ECOlogy is the discipline dealing with the ECOnomy of nature, as the "science of structure and functions of nature, of the interrelationships of organisms among each other and with their environment" (cp. Weigmann, 1985, p. 7 \& seq.). Since ecology asks questions about the interrelations between human communities and biosphere, it has started to develop "from a biological subdiscipline towards a comprehensive task of research with great focusing competence by offering a framework for coordination of the contributions made by various disciplines" (cp. Umweltrat (Environment Council), 1994, pp. 14 \&

3 The overall sum of price and costs during the utilization period normally will be less against buying new products several times

4 cp., besides others, annual publications of World Bank, World Watch Institute, environment ministries/organisations

5 cp. Petri, 1996, p. IV 
68). More pragmatically, ecology can be defined as economy optimized in a really long-range perspective.

Since about 20 years, the insight is growing that this dangerous development is caused by men and the economic system, as established since about a mere 100 years: Industrial production and mass consumption related thereto has led, in a first stage, to saturated markets in most branches and consequently, in a second stage driven by strong competition, to a "throw-away/waste-oriented" society. It is well known, however, that only about $20 \%$ of the world population are enjoying the "advantages" of this kind of economy, whereas the remaining approx. $80 \%$ are also exposed to the negative side effects. As the Austrian ethologist and Nobel Prize winner Konrad Lorenz worked out $(1974$, p. 25), the established economic system is based on ruinous exploitation of natural resources which will not be found in ecosystems not "driven" by men. This overexploitation concerns

- use of the various natural resources as inputs and

- burdening of the ecosystems by emissions and waste as outputs

of production and consumption processes, without considering limited availability and absorbing capacity.

Practitioners as experts and managers, politicians and scientists of most disciplines agree that the kind and direction of economy has to be changed towards sufficient compatibility with the various ecosystems.

The development and realization of corresponding measures may be oriented on the concept of Sustainable Development, to be understood as a vision and guiding idea.

"Sustainable Development means development that meets the needs of the present without compromising the ability of future generations to meet their own needs. It contains within it two key concepts: The concept of 'needs', in particular the essential needs of the world's poor, to which overriding priority should be given; and the idea of limitation imposed by the state of technology and social organization on the environment's ability to meet present and future needs" (World Commission, 1987, p. 43).

Application of the LA without doubt is one important step in this direction. Additionally, this approach opens up new directions for innovation in areas where the limits of technical innovations in the sense of "still more, more functions, more perfection, more speed, etc." - are visible: Innovation beyond "Turbo"-Innovation (Hübner, 1996).

\section{WHO: THE MAIN PARTIES INVOLVED IN THE ECONOMIC SYSTEM}

Generally, three groups represent the main parties, namely decision-makers from political and (semi-) official institutions, companies, and citizens in private households as consumers. In a market economy, 
(1) the politicians and decision-makers in public administration are responsible for the frame conditions considering the kind of economic processes;

(2) decisions on products and production processes are primarily in the responsibility of the company but will be influenced by

(3) the behavior of the citizen related to consuming and buying decisions.

Application of the LA requires changes to be executed primarily by the companies as the pillars of economic systems. Therefore, the next sections are concentrating on them.

\section{HOW: THE NEED FOR INNOVATIVE CHANGES}

\subsection{Main consequences of applying the $L A$}

\section{Decisive consequences are}

- reduced production volume and capacity required for new products

- need for establishing a "reconditioning loop" offering product-related service to customers

- changes within the organizational structure

- consideration of the requirements of reconditioning during product development

- reduction of production-related waste

- reduction of the volume of "old" products and components to be decommissioned during a period, and

- increased resource efficiency.

Altogether, the innovative changes require decisions on the strategic level of corporate management.

\subsection{Prerequisite: Strategic decisions}

Defining the kinds and fields of business and termination of product/market combinations are strategic core decisions. By application of the LA, a new kind of business is created as product-related service. Together with the effects of reduced production volume and increased ecological compatibility, the company will shift from a primarily production oriented towards a production-and-servicedriven company with explicit ecological orientation.

The establishment of a reconditioning loop is the most important organizational/technical innovation required. As differentiation based on the characteristics of the physical product is very limited in the global market, the importance of servicing as an instrument to create differential advantages is generally increasing. Product-related service for product reconditioning goes far beyond the traditional understanding of "servicing": 
(1) Customers have to be convinced of the efficacy (global customer benefit along with low consumption of further natural resources).

(2) In tendency, long-lived products may be more expensive; therefore special financial services such as leasing, or the sale of use instead of the product, which then remains the company's property, are opening up new kinds of service.

(3) As allowance for further technological development must be possible (see section 1), in addition to the processes of "updating" (inspection, maintenance, exchange of "wearing parts", etc.), the processes of technical "upgrading" have to be organized within the reconditioning loop.

(4) The efficiency of reconditioning processes is strongly influenced by the structure of the product, kind and number of components, kind and number of different materials, technological procedures applied for joining, connecting, etc.

All these requirements and considerations of further technological development have to be taken into account during the phase of product development, leading to new kinds of innovation, too: Ease of disassembling, easy exchangeability of wearing parts and assemblies with specific technology, timeless design, existence of recycling procedures compatible with the environment, and similar issues are prevailing (cp. Brinkmann, Ehrenstein \& Steinhilper, 1994).

Consideration of all these aspects, together with reconditioning, provides for a dematerialization in the sense of "lean products" (cp. Hübner, 1993) and, in connection with that, increase of resource efficiency. An approach for determination of the latter has been developed by Schmidt-Bleek, using the measuring unit MIPS (Material Intensity Per Service-Unit): The quantity of nature, in kilograms or tons, (in particular material and energy) required for providing a particular service-unit is measured ${ }^{6}$ (Schmidt-Bleek, 1993). The smaller this "ecological rucksack" of a product, the greater its resource efficiency. According to realistic estimates and examples (cp. section 6), it is possible to increase the resource efficiency by a factor of 5 to $>\mathbf{2 0}$. Indicating specific targets for - e.g. annual - rates of increase of resource efficiency for individual products also belongs to the tasks of corporate management.

Prerequisites for related strategy decisions are changes in the ways of thinking and understanding of economic processes:

- Development, production and selling of always new products

- is not the only source of economic success and growth

- is more and more restricted by ecological constraints.

- Product-related service in the way of reconditioning is an additional source of economic success; consequently.

\footnotetext{
${ }^{6}$ This approach has been used successfully to compare different technologies for high-speed train service systems (cp. Gers et al., 1997)
} 
- The product has to be understood as a potential source for further earnings, also after its delivery to the customer.

- Handling of complaints, supply of spare parts in connection with maintenance are not to be regarded as "troublesome" but as additional business.

- Value creation by the company serves for value preservation of customers' products, too.

- Thinking in circulation (reconditioning, recycling) instead of linear sequences (procurement, production, sale).

\subsection{Consequences for the production (management) system}

Based on related strategic decisions, the production system has to be redesigned. Using the Aspect System Approach, a distinction may be made between the technical-physical and the cybernetic system (Augustin \& Hübner, 1984), each consisting of four partial systems, namely for goals, functions $\&$ instruments, responsibilities, and technical equipment.

Application of the LA influences both the technical-physical and the cybernetic system; primarily by influencing the systems of goals. At the same time, the manufacturing equipment has to be redesigned with respect to requirements for reduced capacity and partly changed product structure as necessary for reconditioning.

Against this, the competence and know-how represented in the cybernetic system - including control and logistics - will remain extremely valuable: not only for "running" further production but also for establishing and running the processes of product reconditioning, including technical updating and upgrading. This also applies for experience in maintenance of technical equipment, which can be adapted and transferred for product reconditioning.

\section{WHEN}

To avoid the dangers of catastrophes caused by collapse of the ecosystems, companies should start or continue immediately in an evolutionary way, oriented on the guiding idea of Sustainable Development. As may be seen by examples described or mentioned in section 6 , a lot of companies are already very successful in the economic sense as "eco-pioneers". Real entrepreneurship is characterized by assumption of societal responsibility without waiting for public administration and politics to change the overall conditions; however, such changes are imminent: Changes in the tax system, together with application of new procedures for calculation of the real, sustainable income of a national economy, are foreseeable according to the new Club-of-Rome Report (cp. Dieren, van, 1995). To meet ecological requirements and to solve the world-wide social problems caused by unemployment, reduction of taxes on human labor combined 
with increased taxes on energy and other natural resources in a way to ensure unchanged overall tax income for public administration are under discussion (cp. Wuppertal-Institut, 1995). Concrete measures of ecological "pioneer states" elucidate these developments: For instance, Austria - after the Netherlands - has adopted a "National Environmental Plan" (Austrian Federal Government, 1995), and Germany passed a law on circulation economy and waste (Kreislaufwirtschafts- und Abfallgesetz, 1994) which obliges companies to take back products after the end of utilization.

\section{EXAMPLES: EXPERIENCE OF OUR DEPARTMENT AND REFERENCE TO DESCRIPTIONS IN LITERATURE}

Examples as a result of cooperation with companies concern washing-machines, heating boilers, and refrigerators for private households. Some results are described in "Berichte aus der TWI-Produktwerkstatt" (Reports from the TWI Product Workshop) edited by the author. The results of one case study, worked out together with the German railways and directly related to the LA (cp. Sporr, 1994), are briefly presented below:

Product: Diesel-driven passenger trains (drive car with center car) of the VT 624/634 series of the German railways; year of construction: 1965; quantity in service: 1005 trains; duration of use originally planned, taking into consideration repair measures including basic overhaul: 30 years.

Decision of the Kassel reconditioning plant of the German railways in 1994: Extensive modernization by updating and upgrading since, on account of the condition of the diesel railcars, a further period of use of about 30 years may be expected, i.e. total period of use around 60 years.

Concrete measures of updating and upgrading for the above-mentioned diesel railcars:

- Change in space layout:

\# Bicycle storage place instead of baggage space

\# Adoption of a first-class compartment due toidentified demand

- Replacement of the electrical mercury-operated DC/AC converters by an ecologically better suited technology

- Improved heat insulation by installing external windows with insulating glass panes etc.

- New design of driver's cab, taking into account findings of manpower studies, operation without conductor

- Installation of automatic doors.

Results:

Economic effects: $\mathbf{5 0} \%$ of costs as against new production.

Ecological effects: Remarkable resource efficiency obtained.

Weight per train: $32.6 \mathrm{t}$ - at least $\mathbf{7 0 \%}$ of the steel used will remain in use for another 30 years, total 60 years, i.e. about $23,000 \mathrm{t}$ for 1005 trains. On the basis 
of material intensity values for steel production from recycling material (Schmidt-Bleek \& Tischner, 1995, p. 132), resource savings of 69,000 tons of material, 1,311,000 tons of water, and 69,000 tons of air will be obtained.

The results of reconditioning passenger cars for InterRegio traveling trains obtained in another reconditioning plant are likewise remarkable:

Weight per old car: 12 tons (almost $100 \%$ of this can be used without modification); reconditioning of 1200 cars saving $1200 \times 12 t=14,400 t$ of new steel and, thereby,: 94.5 mill. kWh of energy (Günther, 1993, p. 256).

\section{CONCLUSION}

Ecological limitations will become more and more of a bottleneck factor for economy. Development and production of always new products, as usual up to now, means wastage of natural resources. The energy necessary for extraction of raw materials and for production, embodied in the product, cannot be recovered any more, and recycling of materials requires additional energy and results in "downcycling" for most of them.

Application of the LA allows to reduce this wastage, and therefore will lead to increasing of resource efficiency with positive ecological as well as economical consequences. The introduction of this approach is a big challenge for all groups involved in the economic system and requires changes in understanding the processes of production and consumption. To increase the duration of product use, companies have to establish a reconditioning loop (Figure 1) for maintenance and upgrading of products, ensuring in this way customer benefit over a long period without the necessity of buying a new product.

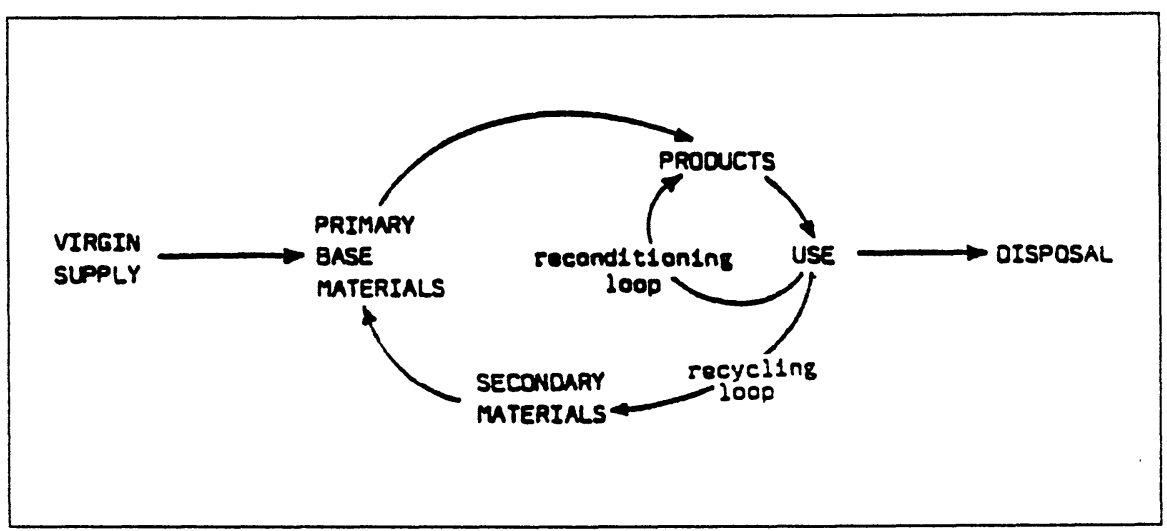

Figure 1 Reconditioning Loop versus Recycling Loop (comp. Stahel \& RedayMulvey, 1991, p 70) 
Application of the LA is possible for products and/or components and provides, besides the desired ecological effects, additional economic benefits for companies, customers, and society.

Broad diffusion and application of the LA may be understood as one important event besides others, oriented on Sustainable Development as a guiding idea, too.

A lot of future activities are required

(1) to sensitize individuals as members of society

(2) to adapt the frame conditions, based on

(3) revised/modified targets, values, ways of thinking and paradigms, to be worked out together with scientists of related disciplines such as economics, social sciences, natural sciences and engineering.

The insight that the quality of life in industrialized countries cannot be increased further by using and consuming more material goods, used as a fundamental thesis in a study on the future development of Germany (comp. BUND, Misereor (Eds.), 1996), may be adopted as a basis for future interdisciplinary work. On the level of national economy, the effects of LA, resulting in shifting of "production" jobs towards more "service" jobs have to be identified and considered in the qualification system. On company level, ongoing research is dealing with factors influencing the organizational and technical structure of reconditioning.

Increasing the efficiency of resource usage is leading, step by step, to "dematerializing" of our economy in the way of using less raw materials and energy without reduction of prosperity,. This process, which will change the established structure of economy, is likely to run over some decades.

With a view to the impressing increase in labor productivity achieved in the industrialized states since the beginning of our century, there is no doubt that the required increase in resource efficiency will be mastered first by the society of the industrialized states, which not only dominate the main part of the world economy but also have to bear the responsibility for this change towards ecologyoriented economic activities.

\section{REFERENCES}

Augustin, S. \& Hübner, H. (1984), Designing Computer Supported Production Management Systems using the Aspect-System-Approach, in Hübner, $\mathrm{H}$. (Ed.): 'Production Management Systems', Amsterdam et al., pp. 51-66.

Austrian Federal Government (Eds.) (1995), Österreich - Nationaler Umweltplan, Wien.

Brinkmann, Th., Ehrenstein, G. \& Steinhilper, R. (1994), Umwelt- und recyclinggerechte Produktentwicklung, WEKA Fachverlag, Augsburg.

BUND \& Misereor (Eds.) (1996), Zukunftsfähiges Deutschland, Birkhäuser Verlag, Basel \& Berlin. 
Dieren, W. van (Ed.) (1995), Taking Nature into Account - A Report to the Club of Rome, Basel.

Gers, V., Hübner, H., Otto, P. \& Stiller, H. (1997), Zur Ressourcenproduktivität von spurgeführten Hochgeschwindigkeitsverkehrssystemen: Ein Vergleich von ICE und Transrapid, Wuppertal Papers Nr. 75, June 1997, TWI (University of Kassel) \& Wuppertal Institut.

Grote, A. (1994), 'Grüne Rechnung': c't-magazin, Issue 12/1994, pp. 92-98.

Günter, D. (1993), Recycling - Ansätze beim Umbau von Reisezugwagen, in VDI (Eds.), 'Recyclinggerechte Produktentwicklung', VDI-Report Nr. 1089, Düsseldorf.

Hübner, H. (1993): Umweltorientierte Produktplanung: 'Der Weg zum "Lean Product"': io Management Zeitschrift 62, Nr. 3/1993, pp. 76-79.

Hübner, H. (1996), Jenseits der "Turbo"-Innovation (paper for a seminar of Wirtschaftskammer Österreich "Neue Technologien: Ausweg aus der Wegwerfgesellschaft"), Baden/Wien (Austria), 29.02./01.03.1996.

Hübner, H. \& Simon-Hübner, D. (1991), Ökologische Qualität von Produkten Ein Leitfaden für Unternehmen, Hessisches Umweltministerium (Eds.), Wiesbaden \& TWI (University of Kassel), ISBN 3-89274-061-5.

Keller, M. (1994), 'Kann Natur denn Mode sein?': Die Zeit, No. 16 of April 15, p. 72 .

Kreislaufwirtschafts- und Abfallgesetz: Gesetz zur Vermeidung, Verwertung und Beseitigung von Abfällen, Bonn, 27 Sept., 1994.

Lorenz, K. (1974), Die acht Todsünden der zivilisierten Menschheit, 8th edn., Pieper, München.

Petri, H. (1996), 'Verzweiflung, Wut, Rache, Gegengewalt - Zwischen Zukunftsangst und Aggression: Kinder und die psychischen Folgen der Umweltbelastung': "Die Presse", Wien, Jan. 20.

Schmidt-Bleek, F. (1993), Wieviel Umwelt braucht der Mensch?: MIPS - das Maß für ökologisches Wirtschaften, Basel et al.

Schmidt-Bleek, F. \& Tischner, U. (1995), Produktentwicklung: Nutzen gestalten - Natur schonen, Vol. 270 of WIFI Publications, Wirtschaftskammer Österreich, Wien (Austria).

Sporr, V. (1994), Existenzsicherung mit langlebigen Produkten: Strategie und Finanzierung, diploma thesis, TWI (University of Kassel).

Stahel, W. \& Reday-Mulvey, G. (1981), Jobs for tomorrow - The potential for substituting Manpower for Energy, Vantage Press, New York et al.

Umweltrat (Rat von Sachverständigen für Umweltfragen) (Eds.) (1994), Umweltgutachten 1994 - Für eine dauerhaft umweltgerechte Entwicklung, Stuttgart.

Weigmann, G. (1985), Ökologie und Umweltforschung, in Jänicke, M., Simonis, U.E. \& Weigmann, G. (Eds.): 'Wissen für die Umwelt, 17 Wissenschaftler bilanzieren', Berlin \& New York.

World Commission on Environment and Development (Eds.) (1987), Our Common Future, Oxford University Press, Oxford \&New York.

Wuppertal-Institut (Eds.) (1995), Towards Sustainable Europe, Wuppertal Paper Nr. 42, 3rd edn., Wuppertal. 
ZVEI - Information; Handelsblatt of April 29/30, 1994, p. 19.

\section{BIOGRAPHY}

Heinz Hübner is head of the Department of Management Science - Technology Impact \& Innovation Research at the University of Kassel/Germany. He assumed this position after about 10 years in industry, followed by an academic career in Austria, which included appointments at the University of Innsbruck and the Institute for Advanced Studies in Vienna as well as research activities in the International Institute for Applied Systems Analysis (IIASA) in Laxenburg near Vienna. His main field of interest is the economic, social, and environmental impact of technological change. He is the author of numerous journal articles and contributions to collective volumes and editor of The Art and Science of Innovation Management (Elsevier, 1986), as well as co-editor of Innovation Strategies, Theoretical Approaches - Experiences - Improvements (Elsevier, 1992) and Recent Essentials in Innovation Management and Research (Gabler, 1995). He is also a member of the Editorial Board of Technovation. 